\title{
A tiopurinkezelés súlyos mellékhatásainak gyakorisága normális tiopurin-S-metiltranszferáz-genotípusú gyulladásos bélbetegségben szenvedő gyermekekben
}

\author{
Tárnok András dr. \\ Pécsi Tudományegyetem, Általános Orvostudományi Kar, Gyermekgyógyászati Klinika, Pécs
}

\begin{abstract}
Bevezetés: A gyulladásos bélbetegség kezelésében alkalmazott tiopurinok (azatioprin és 6-merkaptopurin) metabolizmusában kulcsszerepet játszó tiopurin-S-metiltranszferáz enzim genetikai polimorfizmusa változó enzimaktivitást eredményez. A csökkent enzimaktivitás mieloszuppressziót, kifejezetten magas pedig hepatotoxicitást okoz standard tiopurindózis mellett. Négy allélvariáns (TMPT*2, TMPT*3A, TPMT*3B és TPMT*3C) felelős több mint 95\%-ban a csökkent aktivitásért.

Célkitüzés: A standard vagy csökkentett azatioprindózis ellenére is fellépő súlyos mellékhatások - úgymint csontvelődepresszió, illetve hepatotoxicitás - gyakoriságának vizsgálata a fenti 4 variáns alléllal nem rendelkező gyulladásos bélbeteg gyermekeknél.

Módszer: Retrospektív vizsgálat a Pécsi Tudományegyetem Gyermekgyógyászati Klinikáján gondozott, azatioprinkezelésben részesülő gyulladásos bélbeteg gyermekeknél.

Eredmények: A fenti kritériumoknak 51 beteg felelt meg (44: Crohn-betegség, 7: colitis ulcerosa; a fiúk aránya: 28/51; átlagéletkor a diagnózis idején: 12,4 év). Az azatioprinkezelést két beteg önkényesen elhagyta, egy betegnél súlyos pancreatitis, egy másiknál pedig kifejezett influenzaszerú tünetek miatt állítottuk le. A fennmaradó 47 beteg egyikénél sem jelentkezett májtoxicitás, mely közvetve kifejezetten magas tiopurin-S-metiltranszferáz-aktivitásra utal. Négy betegnél $(8,5 \%) 1 \mathrm{mg} / \mathrm{kg} / \mathrm{nap}$-nál alacsonyabb azatioprindózis esetén is fennáló mieloszuppresszió miatt a kezelést le kellett állítani, $s$ ezt követően maradéktalan volt a csontvelói regeneráció. A fennmaradó 43 betegnél 2,17 $\pm 0,31 \mathrm{mg} / \mathrm{kg} / \mathrm{nap}$ (átlag $\pm \mathrm{SD}$ ) dózisú azatioprinkezelés mellett csontvelő-depressziót nem észleltünk.

Következtetés: Tiopurinkezelés esetén még normális tiopurin-S-metiltranszferáz-genotípus mellett is mindenképpen szükséges a rendszeres laborkontroll a mieloszuppresszió kockázata miatt. Mivel a genotípus meghatározása a 4 leggyakoribb allélt érintette, ritkább variáns(ok) vagy egyéb enzim polimorfizmusa is állhat a fenti 4 csontvelö-depreszsziós eset hátterében. A tiopurinmetabolitok monitorizálása elengedhetetlen segítséget nyújt az egyénre szabott kezelésben, azaz az elérhető legkevesebb mellékhatás mellett az optimális dózis beállításában.
\end{abstract}

Orv Hetil. 2019; 160(5): 179-185.

Kulcsszavak: gyulladásos bélbetegség, azatioprin, 6-merkaptopurin, tiopurin-S-metiltranszferáz, genetikai polimorfizmus

Frequency of serious adverse events of thiopurine treatment in normal thiopurine S-methyltransferase genotype children with inflammatory bowel disease

Introduction: Genetic polymorphism of thiopurine S-methyltransferase, the key enzyme in metabolism of thiopurines (azathioprine and 6-mercaptopurine) used in the treatment of inflammatory bowel disease, results in different enzyme activities. Decreased enzyme activity causes myelosuppression whereas abnormally high activity results in hepatotoxicity at standard thiopurine doses. Four allele variants $\left(\mathrm{TMPT}^{\star} 2, \mathrm{TMPT}^{\star} 3 \mathrm{~A}, \mathrm{TPMT}^{*} 3 \mathrm{~B}\right.$ and $\mathrm{TPMT}^{\star} 3 \mathrm{C}$ ) account for decreased activity in more than $95 \%$ of cases. 
Aim: To evaluate the frequency of severe side effects, such as myelosuppression and hepatotoxicity, at standard or decreased azathioprine doses in children with inflammatory bowel disease who do not exhibit any of the four most common variant alleles.

Method: Retrospective analysis of children with inflammatory bowel disease treated with azathioprine at a single tertiary referral center.

Results: 51 patients were identified (44: Crohn's disease, 7: ulcerative colitis; male ratio: 28/51; mean age at diagnosis: 12.4 years). Two patients discontinued azathioprine arbitrarily whereas in one patient it was stopped due to serious pancreatitis and in another one because of severe flu-like symptoms. None of the remaining 47 patients exhibited hepatotoxicity suggesting abnormally high thiopurine S-methyltransferase activity. Four patients (8.5\%) had profound myelosuppression on less than $1 \mathrm{mg} / \mathrm{kg}$ /day azathioprine requiring discontinuation of the drug, and all of them showed complete bone marrow recovery subsequently. No myelosuppression occurred in the remaining 43 patients on $2.17 \pm 0.31 \mathrm{mg} / \mathrm{kg} /$ day $($ mean $\pm S D)$ azathioprine treatment.

Conclusions: Regular blood tests are necessary on thiopurine therapy despite normal thiopurine S-methyltransferase genotype because of the risk of myelosuppression. The four most common variant alleles were identified in routine genotyping only, therefore most likely rare variant allele(s) or polymorphism of other enzymes involved in thiopurine metabolism account for the aforementioned four cases with profound bone marrow suppression. Thiopurine metabolite monitoring is the key for individualized treatment when optimal dosing can be achieved with the least side effects.

Keywords: inflammatory bowel disease, azathioprine, 6-mercaptopurine, thiopurine S-methyltransferase, genetic polymorphism

Tárnok A. [Frequency of serious adverse events of thiopurine treatment in normal thiopurine S-methyltransferase genotype children with inflammatory bowel disease ]. Orv Hetil. 2019; 160(5): 179-185.

(Beérkezett: 2018. augusztus 13.; elfogadva: 2018. szeptember 15.)

\section{Rövidítések}

6-MP = 6-merkaptopurin; 6-MMP = 6-metil-merkaptopurin 6-TGN = 6-tioguanin nukleotid; $\mathrm{AZA}=$ azatioprin; $\mathrm{CD}=$ (Crohn's disease) Crohn-betegség; ECCO $=$ (European Crohn's and Colitis Organisation) Európai Crohn Colitis Társaság; ESPGHAN = (European Society of Pediatric Gastroenterology Hepatology and Nutrition) Európai Gyermekgasztroenterológiai, Hepatológiai és Táplálkozástudományi Társaság. $\mathrm{IBD}=$ (inflammatory bowel disease $)$ gyulladásos bélbetegség; $\mathrm{MCV}=$ (mean corpuscular volume) átlagos vörösvértestnagyság; NAFLD $=($ non-alcoholic fatty liver disease $)$ nem alkoholos zsírmáj; PTE = Pécsi Tudományegyetem; $\mathrm{SD}=$ standard deviáció; TPMT = tiopurin-S-metiltranszferáz; UC = (ulcerative colitis) colitis ulcerosa; VVT = vörösvértest

A tiopurinok (azatioprin - AZA és 6-merkaptopurin 6-MP) kulcsszerepet játszanak a gyulladásos bélbetegség (inflammatory bowel disease - IBD) kezelésében. A gyermekkori kezdetú IBD a felnőttkorban indulóhoz képest sajnos kedvezőtlenebb fenotípusú, súlyosabb lefolyású, ezért korai agresszív terápia javasolt, melynek a legtöbb esetben részét képezi az AZA-vagy 6-MP-kezelés.

A tiopurinmetabolizmus egyik kulcsfontosságú enzime a tiopurin-S-metiltranszferáz (TPMT). Az AZA-ból, úgynevezett „pro-drug”-ból, a májban 90\%-ban nem enzimatikus hasítás révén körülbelül feleakkora tömegü 6-MP keletkezik. (Ebből adódik, hogy a 6-MP javasolt standard dózisa az AZA-adag mintegy 50\%-a, azaz $1-1,5$ $\mathrm{mg} / \mathrm{kg} / \mathrm{nap}$ versus $2-3 \mathrm{mg} / \mathrm{kg} / \mathrm{nap}$.) Ezt követően a 6-MP 3 kompetitív metabolikus útvonalon alakulhat át.
Az egyik útvonal, amikor többszörös enzimatikus lépések révén keletkezik a tiopurinkezelés hatékonyságáért felelős aktív metabolit, a 6-tioguanin nukleotid (6-TGN), mely purinantagonistaként fejti ki immunszuppresszív hatását, és egyben mieloszuppresszív tulajdonságokkal bír. A másik két útvonal a 6-MP inaktiválódásához vezet, az egyik metilálódás, a másik oxidálódás révén. Metilálódás során a TPMT enzim közremúköódésével a 6-MP-ből 6-metil-merkaptopurin (6-MMP) képződik, mely hepatotoxikus hatású. Oxidálódás során pedig a 6-MP-t a xantin-oxidáz hatástalanítja, és 6-tiourinsav keletkezik. A xantin-oxidáz ugyanakkor az első útvonal során keletkező hatékony metabolitnak, a 6-TGN-nak a lebontását is végzi. Emiatt xantin-oxidáz-gátló szedése tiopurinkezelés során különös óvatosságot igényel. A tiopurinmetabolizmus fóbb lépéseit az 1 . ábra mutatja.

A TPMT-gén monogénesen, kodominánsan öröklődik, polimorfizmusa jól ismert. A normális, úgynevezett 'vad' allélhez (TPMT*1) képest a TPMT enzimet kódoló gén több mint 40 variánsáról ismert, hogy csökkent vagy hiányzó TPMT-aktivitást okoz. Ezek közül 3 allél, a TMPT*2, a TMPT*3A és a TPMT*3C felelős körülbelül 95\%-ban a csökkent aktivitásért [1]. Azonos allélen lévő két - a TPMT*3B- és a TPMT*3C-allélt létrehozó - mutáció kombinációja révén alakul ki a TPMT*3A-allél, mely a kaukázusi népcsoport leggyakoribb, inaktivitásért felelős variáns allélja, mintegy $5 \%$-os gyakorisággal ebben a populációban [2].

Csökkent vagy hiányzó TPMT-aktivitás esetén a metabolizmus a 6-TGN-képződés irányába tolódik el, mely 


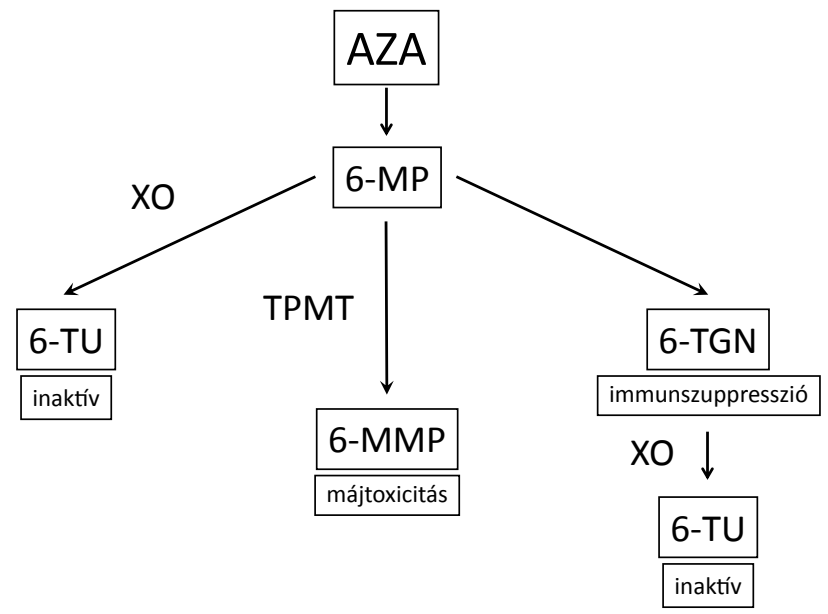

1. ábra

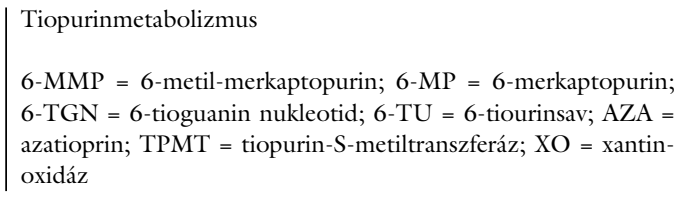

mielotoxikus mellékhatással jár. Ugyanakkor a normálishoz képest nagyon magas TPMT-aktivitás ('hipermetiláló' egyén) esetén aránytalanul kevés 6-TGN és sok 6-MMP keletkezik, ami miatt csekély klinikai hatás mellett fokozott hepatotoxicitás várható standard tiopurindózis mellett.

A közös ECCO-ESPGHAN ajánlás szerint gyermekkori IBD-ben tiopurinkezelést megelőzően a TPMT-genotípus vagy TPMT-aktivitás (fenotípus) meghatározása javasolt [3]. Normális TPMT-genotípus vagy -aktivitás esetén standard tiopurindózis adandó. Heterozigóta TPMT-genotípus (intermedier aktivitás) esetén, mely a populáció körülbelül 11\%-át érinti, a standard dózis fele javasolt, míg homozigóta TPMT-variáns genotípus (TPMT-deficientia) esetén (ez a populáció mintegy 3 ezrelékét érinti) nem javasolt tiopurin alkalmazása a súlyos csontvelő-depresszió kockázata miatt.

A Pécsi Tudományegyetem Gyermekgyógyászati Klinikáján 2013 áprilisa óta az IBD-s betegeknél a korábbi sporadikus TPMT-genotípus-meghatározás helyett a rutinszerü TPMT-genotípus-meghatározás került bevezetésre. A jelen tanulmány célkitüzése az volt, hogy a fenti időponttól rutinszerüen TPMT-meghatározáson áteső, a leggyakoribb (TMPT*2, TMPT *3A, TPMT*3B és/ vagy TPMT*3C) variánssal nem rendelkező, „normális” TPMT-genotípusú, IBD-s gyermekeknél standard vagy csökkentett AZA-dózis ellenére is fellépő súlyos mellékhatások - úgymint csontvelö-depresszió, illetve hepatotoxicitás - gyakoriságát felmérje.

\section{Módszer}

Retrospektív vizsgálat során a tiopurinkezelés okozta súlyos mellékhatások kerültek feldolgozásra a PTE Gyermekklinikáján gondozott, 2013. április 1. és 2018. júni- us 30. között genetikai vizsgálaton átesett, $\mathrm{TMPT}^{*} 2$, $\mathrm{TMPT}^{*} 3 \mathrm{~A}, \mathrm{TPMT}^{*} 3 \mathrm{~B}$ és/vagy TPMT ${ }^{*} 3 \mathrm{C}$ variáns allél egyikével sem rendelkező, AZA-kezelésben korábban vagy aktuálisan részesülő IBD-s gyermekek elektronikus és papíralapú dokumentációjának és genetikai vizsgálati eredményének felhasználásával.

A vizsgálatból az alábbi gyermekek kerültek kizárásra:

1. TMPT *2-, TMPT *3A-, TPMT*3B- és/vagy $\mathrm{TPMT}^{*} 3 \mathrm{C}$-allélt hordozó, intermedier vagy alacsony TPMT-aktivitásra utaló genotípusú, valamint

2. a fenti variáns allélok egyikét sem hordozó, klinikánkon diagnosztizált, de AZA-terápiában a késóbbiekben más intézetben részesülő vagy klinikánkon AZA-kezelésben soha nem részesülő IBD-s gyermekek.

A TPMT-polimorfizmus meghatározása (TPMT*2, - ${ }^{*} \mathrm{~A}$, - *3B és - ${ }^{\star} 3 \mathrm{C}$ ) a Pécsi Tudományegyetem Orvosi Genetikai Intézetében történt.

Mind az AZA, mind a 6-MP dózisa testtömeg $/ \mathrm{kg} /$ nap formában lett feltüntetve.

A súlyos csontvelő-depresszió kritériuma az abszolút granulocytaszám ismételten 1 G/l alatti értéke, míg a hepatotoxicitásnak a tiopurinkezelést megelőzően normális tartományban levő transzaminázoknak (aszpartátaminotranszferáz vagy alanin-aminotranszferáz) ismételten a korspecifikus normálérték felső határát kétszeresen meghaladó értéke volt $[4,5]$. A fenti kritériumok bármelyikének teljesülése az AZA-dózis ismételten történő megfelezését vonta maga után mindaddig, amíg a hepatotoxicitás vagy mieloszuppresszió megszűnt, vagy az AZA-terápia annak minimális ( $1 \mathrm{mg} / \mathrm{kg} /$ nap-nál alacsonyabb) dózisa miatt leállításra került.

A súlyos fertőzés definíciójaként a Common Terminology Criteria for Adverse Events (CTCAE v5.0) skála Grade 3-5 kategóriái feleltek meg [6].

A betegek párhuzamos, a TPMT-aktivitást befolyásoló gyógyszerei ismertek voltak.

A betegeknél nem került sor az aktív (6-TGN) és a toxikus (6-MMP) metabolit szintjének meghatározására.

\section{Eredmények}

A fenti beválasztási kritériumoknak 51 beteg felelt meg: 44 Crohn-betegségben (CD) és 7 colitis ulcerosában (UC) szenvedő gyermek, 28 fiú és 23 lány. Átlagéletkoruk a diagnózis idején 12,4 (tartomány: 4,7-17,7) év volt. A demográfiai adatokat az 1. táblázat tartalmazza. Az AZA-kezelést két beteg (CD-lány és UC-fiú) önkényesen elhagyta; egy fiúnál (CD) AZA-, majd ezt követően 6-MP-kezelés során is konzekvensen jelentkező kifejezett influenzaszerü tünetek miatt, míg egy lánynál (UC) egyszeri AZA-dózis okozta súlyos pancreatitis miatt voltunk kénytelenek a tiopurinkezelést leállítani. A fennmaradó 47 beteg (42 CD, ezen belül 24 fiú, illetve 5 UC, ezen belül 2 fiú; átlagéletkor a diagnózis idején: 12,3 év) egyikénél sem jelentkezett májtoxicitás, mely közvetve fokozott TPMT-aktivitásra utal. Azonban 4 CD-betegnél $(8,5 \%)$ - 2 fiú és 2 lány - az AZA-kezelés 
1. táblázat | Demográfiai adatok

\begin{tabular}{lccc}
\hline & A betegek száma $(\mathrm{n}=51)$ & Crohn-beteg $(\mathrm{n}=44)$ & Colitis ulcerosa $(\mathrm{n}=7)$ \\
\hline A fiúk száma (aránya, \%) & $28(55 \%)$ & $25(57 \%)$ & $3(43 \%)$ \\
\hline Átlagéletkor a diagnózis idején (tartomány) & 12,4 év $(4,7-17,7)$ & 12,4 év $(4,7-17,7)$ & 12,2 év $(9,4-16,9)$ \\
\hline
\end{tabular}

leállítását indokló súlyos csontvelő-depressziót észleltünk. Mindegyiküknél fennállt a csontvelő-depresszió 1 $\mathrm{mg} / \mathrm{kg} / \mathrm{nap}$, illetve ennél alacsonyabb AZA-dózis esetén is, „normális” TPMT-genotípus ellenére, ugyanakkor az AZA leállítását követően maradéktalan volt a csontvelői regeneráció. A fennmaradó 43 betegnél (38 CD, ezen belül 22 fiú; illetve 5 UC, ezen belül 2 fiú) „normális” TPMT-genotípus mellett $2,17 \pm 0,31 \mathrm{mg} / \mathrm{kg} / \mathrm{nap}$ (átlag \pm SD) AZA-dózisú kezelésnél csontvelő-depressziót nem észleltünk.

\section{Megbeszélés}

A kaukázusi népcsoportban a TPMT * $1 /{ }^{*} 1$ ('vad' típus) genotípus aránya körülbelül $89 \%$, mely normális TPMTaktivitással társul. A fennmaradó mintegy 11\%-ban azonban az egyik 'vad' allél helyett egy variáns (akár nem funkcionáló, akár csökkent aktivitást okozó) allél van jelen (heterozigóta genotípus), mely intermedier, csökkent TPMT-aktivitást idéz elő. Körülbelül 1 : 300 annak lehetősége, hogy mindkét allél variáns legyen, aminek következménye hiányzó vagy minimális TPMT-aktivitás [7].

A 2014-ben megjelent közös ECCO-ESPGHAN ajánlás szerint gyermekkori IBD-ben a TPMT-genotípus vagy -fenotípus meghatározása javasolt tiopurinkezelést megelőzően. Ugyanakkor a PTE Gyermekklinikáján már 2013 áprilisa óta végzünk rutinszerúen TPMT-genotípus-meghatározást IBD-s gyermekeknél. A vizsgált nem funkcionáló allélok (TPMT*2, - ${ }^{\star} 3 \mathrm{~A},{ }^{*} 3 \mathrm{~B}$ és - $3 \mathrm{C}$ ) körülbelül 95\%-ban felelősek a hiányzó TPMT-aktivitásért. $\mathrm{Az}$ egyes variáns allélok frekvenciája népcsoportonként eltérő lehet, például a TPMT*3C az afrikai, míg a TPMT*3A a kaukázusi népcsoportban a leggyakoribb (az összes mutáns allél 52\%-a, illetve 86\%-a), azonban a mutáns allélok összgyakorisága a két népcsoportban hasonló [8]. A variáns allélok frekvenciája egy adott populációban nem különbözik IBD-ben szenvedő vagy nem IBD-s egyénekben [9].

A TPMT-status meghatározásának másik lehetséges módja az enzimaktivitás direkt mérése (fenotípus meghatározása) vörösvértestekben (VVT-ben), mely jól korrelál a fehérvérsejtekben mérhető aktivitással. Azonban uraemia, illetve a közelmúltban történt vértranszfúzió esetén a vizsgálat pontatlan. Ezenkívül még bizonyos gyógyszerek is megváltoztathatják a TPMT enzim aktivitását - mint például az AZA önmaga -, vagy a diuretikumok növelhetik, míg az 5-aminoszalicilátok csökkenthetik az aktivitást, illetve a leukaemia kapcsán bekövetkező atípusos haematopoesis tévesen alacsony értéket okozhat $[1,9]$. A TPMT-aktivitás idővel egyénenként is változik. Az enzimaktivitás mérésével a normálishoz képest nagyon magas TPMT-aktivitású ('hipermetiláló') egyén is beazonosítható.

A TPMT-genotípus meghatározása a fentieket kiküszöböli, és a csökkent TPMT-aktivitású betegek döntő többségét azonosítani tudja, azonban a ritka variáns allélekre nem terjed ki, és a nagyon magas aktivitású egyéneket sem tudja kiszürni.

Az előbbiekből következik, hogy mind a genotípus, mind a fenotípus meghatározásának vannak előnyei és hátrányai is. Észszerű ötletnek tûnik a TPMT-statust először enzimaktivitással meghatározni (természetesen a fent említett befolyásoló tényezők hiánya esetén), majd pedig az intermedier vagy alacsony TPMT-aktivitást a genotípus meghatározásával megerősíteni. Ez a megközelítés azonban nem terjedt el a gyakorlatban, és intézményenként általában csak az egyik módszert alkalmazzák.

Az IBD-terápia sarokköve az immár több mint 30 éve alkalmazott tiopurinkezelés, mely monoterápiában, illetve kombinációban is hatékonynak bizonyult. Mivel a tiopurinok terápiás hatása körülbelül 3 hónap alatt épül fel, értelemszerúen csak fenntartó kezelés céljából jöhetnek szóba. A TPMT-status meghatározása a tiopurin kezdeti dózisának megválasztásához ad támpontot, azonban a dózistitrálásban ('finomhangolásban') a későbbiekben már nem segít. Mind a hepatotoxicitás, mind a mieloszuppresszió korai felismerésében, illetve megelőzésében elengedhetetlenek a rendszeres laborvizsgálatok (vérkép, 'májfunkció'). Az egyénre szabott tiopurinkezeléshez, vagyis a 'finomhangoláshoz' a fenti rutinlaborokon kívül az aktív és a toxikus metabolit szintjének ismerete szükséges, ugyanis a testtömeg alapján történő tiopurinadagolás ellenére egyénenként jelentősen eltérhetnek az aktív-, illetve toxikusmetabolit-szintek, melyeket nemcsak a TPMT-polimorfizmus, hanem egyéb tényezők is - mint például a gyógyszerfelszívódás, -eloszlás, -kölcsönhatás és -kiürülés - befolyásolnak. A VVT-ben mérhető 6-TGN-koncentráció - mely fordítottan arányos a TPMT-aktivitással - jól korrelál a mielotoxikus, míg a 6-MMP-szint - mely egyenesen arányos a TPMTaktivitással - a májkárosító hatással. A klinikai válasz jól korrelál a VVT-ben mérhető 6-TGN-koncentrációval [4]. 6-TGN esetén $450 \mathrm{pmol} / 8 \times 10^{8} \mathrm{VVT}$ feletti tartományban magas a mielotoxicitás, a leukopenia kockázata, míg $235 \mathrm{pmol} / 8 \times 10^{8}$ VVT-szint alatt csekély a terápiás válasz, emiatt a $235-450 \mathrm{pmol} / 8 \times 10^{8} \mathrm{VVT}$ - 
2. táblázat |A tiopurinmetabolit-mérés gyakorlati haszna aktív gyulladásos bélbetegségben

\begin{tabular}{|c|c|c|c|c|c|}
\hline 6-TGN-szint & Nem mérhető & $\begin{array}{l}235 \mathrm{pmol} / 8 \times 10^{8} \mathrm{VVT} \\
\text { alatt }\end{array}$ & $\begin{array}{l}235 \mathrm{pmol} / 8 \times 10^{8} \mathrm{VVT} \\
\text { alatt }\end{array}$ & $\begin{array}{l}450 \mathrm{pmol} / 8 \times 10^{8} \mathrm{VVT} \\
\text { felett }\end{array}$ & $\begin{array}{l}450 \mathrm{pmol} / 8 \times 10^{8} \mathrm{VVT} \\
\text { felett }\end{array}$ \\
\hline 6-MMP-szint & Nem mérhető & $\begin{array}{l}5700 \mathrm{pmol} / 8 \times 10^{8} \mathrm{VVT} \\
\text { alatt }\end{array}$ & $\begin{array}{l}5700 \mathrm{pmol} / 8 \times 10^{8} \mathrm{VVT} \\
\text { felett }\end{array}$ & $\begin{array}{l}5700 \mathrm{pmol} / 8 \times 10^{8} \mathrm{VVT} \\
\text { alatt }\end{array}$ & $\begin{array}{l}5700 \mathrm{pmol} / 8 \times 10^{8} \mathrm{VVT} \\
\text { felett }\end{array}$ \\
\hline Értékelés & Nonadherencia & Aluldozírozás & $\begin{array}{l}\text { Nagyon magas TPMT- } \\
\text { aktivitás } \\
\text { ('Hipermetiláló' egyén) } \\
\text { Hepatotoxicitás veszélye }\end{array}$ & $\begin{array}{l}\text { Alacsony TPMT-aktivitás } \\
\text { Tiopurinrefrakteritás } \\
\text { Mieloszuppresszió } \\
\text { veszélye }\end{array}$ & $\begin{array}{l}\text { Túladagolás és tiopurin- } \\
\text { refrakteritás } \\
\text { Mieloszuppresszió és } \\
\text { hepatotoxicitás veszélye }\end{array}$ \\
\hline Javaslat & Edukáció & Dózisemelés & $\begin{array}{l}\text { Dózisredukció + } \\
\text { allopurinol }\end{array}$ & $\begin{array}{l}\text { Más gyógyszer választása } \\
\text { A tiopurinkezelés } \\
\text { folytatása dózisredukció- } \\
\text { val aktív betegség miatt } \\
\text { nem jön szóba }\end{array}$ & $\begin{array}{l}\text { Más gyógyszer választása } \\
\text { A tiopurinkezelés } \\
\text { folytatása dózisredukció- } \\
\text { val aktív betegség miatt } \\
\text { nem jön szóba }\end{array}$ \\
\hline
\end{tabular}

6-TGN = 6-tioguanin nukleotid. Javasolt terápiás tartomány: 235-450 pmol $/ 8 \times 10^{8}$ VVT között;

6-MMP = 6-metil-merkaptopurin. Javasolt terápiás tartomány: $5700 \mathrm{pmol} / 8 \times 10^{8} \mathrm{VVT}$ alatt;

TPMT = tiopurin-S-metiltranszferáz; VVT = vörösvértest

tartományon belüli 6-TGN-szint javasolt. 6-MMP esetén pedig az $5700 \mathrm{pmol} / 8 \times 10^{8} \mathrm{VVT}$ alatti szint tartása javasolt a májkárosító mellékhatás minimalizálása érdekében $[10,11]$. A fenti két metabolit egyidejű mérésével nemcsak a tiopurindózis állítható be jól, hanem a nonadherenciára, a tiopurinrefrakter, valamint a 'hipermetiláló' állapotra is fény derülhet (2. táblázat). Kifejezetten magas TPMT-aktivitás esetén jelentős dózisredukció (a standard dózis körülbelül 1/10-e) mellett allopurinol adása hatékony tiopurinkezelést tehet lehetővé hepatotoxicitás nélkül.

A javasolt standard AZA-dózis normális TPMT-aktivitás estén 2-3 mg/kg/nap, intermedier aktivitás esetén pedig körülbelül $1 \mathrm{mg} / \mathrm{kg} /$ nap. Klinikai gyakorlatunkban a fent említett leggyakoribb variáns allélokat nem hordozó gyermekeket normális TPMT-aktivitásúnak véleményeztük, így standard, $2-3 \mathrm{mg} / \mathrm{kg} / \mathrm{nap}$ AZA-kezelésben részesültek.

Gyulladásos bélbetegség esetén gyakoribb a májenzim-emelkedés, ami extraintestinalis manifesztációként társuló máj- és epeúti megbetegedést jelezhet (például primer szklerotizáló cholangitis, autoimmun hepatitis). A nem alkoholos zsírmáj (non-alcoholic fatty liver disease - NAFLD), amelynek meredeken emelkedő prevalenciája sajnos a gyermekkorú lakosságot is érinti, szintén májenzim-emelkedéssel jár. Ugyanakkor az IBD-ben szenvedő betegekben gyakoribb a NAFLD (prevalencia: 6,2-40\%), melynek kockázati tényezői között szerepel a bélflóra megváltozása, dysbiosisa, a betegség aktivitása, kiterjedése és a szisztémás kortikoszteroidkezelés is [1215]. Differenciáldiagnosztikai szempontból a tiopurinkezelés okozta hepatotoxicitás megítélésében az előbbieket is figyelembe kell venni.

A jelen vizsgálatban a tartósan AZA-kezelésben részesülő 47 beteg, illetve a kezelést önkényesen elhagyó 2 gyermek közül egynél sem észleltünk hepatotoxicitást, mely közvetve 'hipermetiláló' állapotra, azaz kifejezetten magas TPMT-aktivitásra utalt volna.
Négy esetben $(8,5 \%)$ azonban a fenti standard AZAdózis alkalmazásakor olyan mértékű csontvelő-depreszszióra utaló laboreltéréseket észleltünk, melyek miatt az AZA-kezelést le kellett állítanunk, ugyanis $1 \mathrm{mg} / \mathrm{kg} /$ nap, illetve ennél alacsonyabb dózis esetén is fennállt a mieloszuppresszió (az abszolút granulocytaszám 1 G/1 alatti volt). A csontvelő-depresszió egyik betegnél sem járt fertőzéses vagy egyéb szövődménnyel, és a csontvelői regeneráció maradéktalan volt az AZA-kezelés leállítását követően. A mieloszuppresszió létrejöttében egyéb gyógyszer interakciója (például allopurinol vagy metamizol szedése), illetve az infekció kizárható volt. Kiváltó okként nagy valószínúséggel egyéb ritkább variáns TPMT-allél(ok) jelenléte, esetleg a tiopurinmetabolizmusban részt vevő egyéb enzimek polimorfizmusai jöhetnek szóba, amit további részletes genetikai vizsgálat igazolhat.

Az ázsiai népcsoportban a variáns TPMT-allélok ritkábban fordulnak elő, mint az európai népcsoportban, ennek ellenére az európai népcsoporthoz képest jóval gyakoribb a tiopurin okozta mieloszuppresszió. Ennek hátterében 2014-ben sikerült azonosítani a NUDT15gén egyik variánsát, mely a tiopurinok csökkent metabolizmusa révén alopeciát és leukopeniát okoz, és az ázsiai népcsoportban jóval gyakoribb, mint az európaiban ( $10 \%$ versus $0,4 \%$ ) [16]. A jelen vizsgálatban részt vevő gyermekek mind az európai népcsoportba tartoztak.

A TPMT-genotípus meghatározásakor 3 betegnél igazoltunk heterozigóta genotípust ( $3 \mathrm{~A}$ variáns allélt), náluk csökkentett AZA-dózis $(1,2 \mathrm{mg} / \mathrm{kg} / \mathrm{nap} \pm 0,07$, átlag \pm SD) mellett nem észleltünk mieloszuppressziót.

A tiopurin okozta pancreatitis ismert, ritka szövődmény (gyakorisága 0-5\%), mely dózisfüggetlen, idioszinkráziás reakcióra és nem a tiopurinmetabolizmusra vezethető vissza [17]. Amennyiben az első hónapokban nem alakul ki tiopurin indukálta pancreatitis, akkor egyéb rizikófaktorok hiányában - ezzel a szövődménnyel nagy valószínúséggel nem kell számolni a későbbiekben. 
A vizsgált periódusban egy betegnél (2\%) alakult ki AZA indukálta pancreatitis (már az első tabletta bevételét követően 24 órán belül), mely miatt az AZA-kezelést fel kellett függeszteni.

Az AZA-kezelés további mellékhatásaként ismert az influenzaszerü tünetek (láz, myalgia, arthralgia, fáradékonyság) megjelenése, melyek 6-MP-re váltást követően megszünhetnek. Betegeink közül 1 esetben azonban még a 6-MP-re történő váltás sem hozott változást, és a konzekvensen jelentkező magas láz, kifejezett izomfájdalom, arthralgia és fáradékonyság miatt a tiopurinkezelést végleg le kellett állítanunk.

A tiopurinkezelés mellékhatásai között ritkán súlyos fertőzés, illetve malignus megbetegedés is elöfordulhat. A jelen tanulmányban részt vevő gyermekek egyikénél sem fordult elő sem súlyos fertőzés, sem malignus megbetegedés.

A tiopurinkezelés IBD-ben sajnos körülbelül 30-50\%ban leállításra kerül, részben mellékhatások (mieloszuppresszió, hepatotoxicitás, pancreatitis stb., összesen több mint 20\%), részben hatástalanság (körülbelül 15\%) miatt [18]. Az egyénre szabott kezelés során a tiopurinmetabolitok (6-TGN és 6-MMP) mérése segít mind a magas 6-TGN-szint okozta csontvelő-depresszió, mind a magas 6-MMP-szint által kiváltott hepatotoxicitás elkerülésében, másrészt a terápiás tartományon belüli 6-TGNszint biztosítása elősegíti a klinikai választ, vagyis a mellékhatások és a hatástalanság csökkentése révén az aktív tiopurinkezelésben részesülők aránya növelhető.

Tiopurinkezelés során - függetlenül attól, hogy a kezelést megelőzően történt-e vagy elérhető volt-e a TPMT-genotípus vagy -fenotípus meghatározása - az első 3 hónapban 2 hetente javasolt a vérkép és a májfunkciók ellenőrzése, mivel a mielotoxicitás a betegek többségében az első hónapokban alakul ki [19]. A későbbiekben - változatlan tiopurindózis esetén - a vérkép és a májfunkció kontrollja havonként ismétlendő, majd később 2, maximum 3 havonkéntire tolható ki a tiopurinkezelés ideje alatt. Ha tiopurindózis-emelés történik, úgy javasolt a kezdeti gyakoribb laborkontrollokra viszszatérni. Amennyiben lehetőség van a tiopurinmetabolitok mérésére, úgy ezt a kezelést követően 4 héttel javasolt először elvégezni, mely egyrészt az adherenciáról ad felvilágosítást, másrészt a hepatotoxicitást, illetve a mielotoxicitást jelezheti előre, és segíti a dózis optimalizálását. A későbbiekben 12-16 héttel a kezelést követően javasolt a metabolitok meghatározása, amikorra azok koncentrációja várhatóan 'stabilizálódik'. Fenntartó kezelés során változatlan tiopurindózis mellett a későbbiekben relapsus, adherencia kérdése vagy toxicitás gyanúja esetén érdemes ismét tiopurinmetabolit-meghatározást végezni [20]. A tiopurinmetabolitok meghatározására azonban sok helyen nincs lehetőség. Az aktív metabolitot (6-TGN) helyettesítő, úgynevezett 'surrogate' marker a VVT átlagos nagyságának (mean corpuscular volume - MCV) változása a tiopurinkezelés alatt [19]. A SONIC-vizsgálat post-hoc analízise szerint a MCV 7 fl- nél nagyobb arányú növekedése szignifikánsan jobb szteroidmentes remisszióval társult AZA-monoterápia során

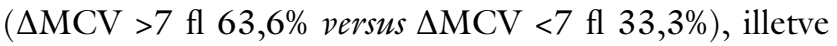
mucosagyógyulással az AZA + infliximab kombinációs kezelés esetén $(\triangle \mathrm{MCV}>7$ fl $75 \%$ versus $\triangle \mathrm{MCV}<7 \mathrm{fl}$ $47,1 \%)[21]$.

\section{Következtetés}

Fontos hangsúlyozni, hogy tiopurinkezelés mellett elengedhetetlen a rendszeres laborkontroll a csontvelö-depresszió kockázata miatt még 'normális' TPMT-genotípus mellett is. Mivel a genotípus meghatározása klinikánkon csak a 4 leggyakoribb variáns allélt érinti, ritkább variáns(ok), illetve a tiopurinmetabolizmusban részt vevő egyéb enzimek polimorfizmusai szerepelhetnek a fent említett 4 betegnél, akiknél csökkentett AZA-dózis ellenére is kifejezett mielotoxicitást észleltünk. Ennek tisztázásában a teljes TPMT-gén szekvenálása, illetve a NUDT15-gén-polimorfizmusok meghatározása segíthet. A tiopurinok komplex metabolizmusa és az abban részt vevő TPMT enzim genetikai polimorfizmusa miatt mind az aktív (6-TGN), mind a toxikus metabolit (6MMP) mennyisége betegenként jelentősen különbözhet. A fenti metabolitok monitorizálása elengedhetetlen segítséget nyújt az egyénre szabott kezelésben, azaz az elérhető legkevesebb mellékhatás mellett az optimális dózis beállításában.

Anyagi támogatás: A közlemény megírása, illetve a kapcsolódó kutatómunka anyagi támogatásban nem részesült.

A szerző a cikk végleges változatát elolvasta és jóváhagyta.

Érdekeltségek: A szerzőnek nincsenek érdekeltségei.

\section{Köszönetnyilvánítás}

A szerző köszönetét fejezi ki a Pécsi Tudományegyetem Orvosi Genetikai Intézetének a genetikai vizsgálatok elvégzéséért.

\section{Irodalom}

[1] Dean L. Azathioprine therapy and TPMT genotype. In: Pratt V, McLeod H, Rubinstein W, et al. (eds.) Medical genetics summaries [Internet]. National Center for Biotechnology Information (US), Bethesda, MD, 2012 Sep 20 (updated 2016 May 3) [accessed: September 14, 2018].

[2] Schaeffeler E, Fischer C, Brockmeier D, et al. Comprehensive analysis of thiopurine $S$-methyltransferase phenotype-genotype correlation in a large population of German-Caucasians and identification of novel TPMT variants. Pharmacogenetics 2004; 14: 407-417

[3] Ruemmele FM, Veres G, Kolho KL, et al. Consensus guidelines of ECCO/ESPGHAN on the medical management of pediatric Crohn's disease. J Crohns Colitis 2014; 8: 1179-1207. 
[4] Dubinsky MC, Lamothe S, Yang HY, et al. Pharmacogenomics and metabolite measurement for 6-mercaptopurine therapy in inflammatory bowel disease. Gastroenterology 2000; 118: 705713.

[5] Wong DR, Coenen MJ, Derijks LJ, et al. Early prediction of thiopurine-induced hepatotoxicity in inflammatory bowel disease. Aliment Pharmacol Ther. 2017; 45: 391-402.

[6] Common terminology criteria for adverse events (CTCAE) v5.0. Available from: https://ctep.cancer.gov/protocolDevelopment/electronic_applications/docs/CTCAE_v5_Quick_ Reference_5x7.pdf [accessed: September 14, 2018].

[7] Weinshilboum R, Sladek S. Mercaptopurine pharmacogenetics: monogenic inheritance of erythrocyte thiopurine methyltransferase activity. Am J Hum Genet. 1980; 32: 651-662.

[8] Hon YY, Fessing MY, Pui CH, et al. Polymorphism of the thiopurine S-methyltransferase gene in African-Americans. Hum Mol Genet. 1999; 8: 371-376.

[9] Gearry RB, Barclay ML. Azathioprine and 6-mercaptopurine pharmacogenetics and metabolite monitoring in inflammatory bowel disease. J Gastroenterol Hepatol. 2005; 20: 1149-1157.

[10] Bradford K, Shih DQ. Optimizing 6-mercaptopurine and azathioprine therapy in the management of inflammatory bowel disease. World J Gastroenterol. 2011; 17: 4166-4173.

[11] Benkov K, Lu Y, Patel A, et al. Role of thiopurine metabolite testing and thiopurine methyltransferase determination in pediatric IBD. J Pediatr Gastroenterol Nutr. 2013; 56: 333-340.

[12] Chao CY, Battat R, Al Khoury A, et al. Co-existence of non-alcoholic fatty liver disease and inflammatory bowel disease: a review article. World J Gastroenterol. 2016; 22: 7727-7734.

[13] Halmos T, Suba I. Non-alcoholic fatty liver disease, as a component of the metabolic syndrome, and its causal correlations with other extrahepatic diseases. [A nem alkoholos zsírmáj mint a metabolikus szindróma komponense és kauzális kapcsolatai egyéb kórképekkel.] Orv Hetil. 2017; 158: 2051-2061. [Hungarian]
[14] Sartini A, Gitto S, Bianchini M, et al. Non-alcoholic fatty liver disease phenotypes in patients with inflammatory bowel disease. Cell Death Dis. 2018; 9: 87.

[15] Egresi A, Kovács A, Szilvás Á, et al. Gut-liver axis in inflammatory bowel disease. A retrospective study. [A bél-máj tengely vizsgálata colitis ulcerosában. Retrospektív tanulmány.] Orv Hetil. 2017; 158: 1014-1021. [Hungarian].

[16] Yang SK, Hong M, Baek J, et al. A common missense variant in NUDT15 confers susceptibility to thiopurine-induced leukopenia. Nat Genet. 2014; 46: 1017-1020.

[17] Teich N, Mohl W, Bokemeyer B, et al. Azathioprine-induced acute pancreatitis in patients with inflammatory bowel diseases - a prospective study on incidence and severity. J Crohns Colitis 2016; 10: 61-68

[18] Jharap B, Seinen ML, de Boer NK, et al. Thiopurine therapy in inflammatory bowel disease patients: analyses of two 8-year intercept cohorts. Inflamm Bowel Dis. 2010; 16: 1541-1549.

[19] Dart RJ, Irving PM. Optimising use of thiopurines in inflammatory bowel disease. Expert Rev Clin Immunol. 2017; 13: 877888.

[20] Goel RM, Blaker P, Mentzer A, et al. Optimizing the use of thiopurines in inflammatory bowel disease. Ther Adv Chronic Dis. 2015; 6: 138-146.

[21] Bouguen G, Sninsky C, Tang KL, et al. Change in erythrocyte mean corpuscular volume during combination therapy with azathioprine and infliximab is associated with mucosal healing: a post hoc analysis from SONIC. Inflamm Bowel Dis. 2015; 21 : 606-614.

\section{"Amicum proba, probatum ama!" (A barátot próbáld ki, ha pedig kiállta a próbát, szeresd!)}

(Tárnok András dr., Pécs, József A. u. 7., 7623 e-mail: tarnok.andras@pte.hu)

\footnotetext{
A cikk a Creative Commons Attribution 4.0 International License (https://creativecommons.org/licenses/by/4.0/) feltételei szerint publikált Open Access közlemény melynek szellemében a cikk bármilyen médiumban szabadon felhasználható, megosztható és újraközölhetö, feltéve, hogy az eredeti szerző és a közlés helye, illetve a CC License linkje és az esetlegesen végrehajtott módositások feltüntetésre kerülnek. (SID_1)
} 